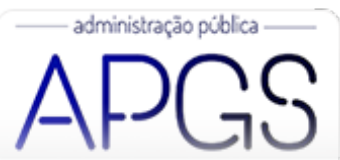

Administração Pública e Gestão Social ISSN: 2175-5787

apgs@ufv.br

Universidade Federal de Viçosa

Brasil

\title{
Hegemonia do Planejamento Urbano Estratégico e o Discurso Contra- Hegemônico do Direito à Cidade
}

Leandro Santos, Jouberte Maria; Carvalho Benício de Mello, Sérgio

Hegemonia do Planejamento Urbano Estratégico e o Discurso Contra-Hegemônico do Direito à Cidade

Administração Pública e Gestão Social, vol. 12, núm. 2, 2020

Universidade Federal de Viçosa, Brasil

Disponible en: http://www.redalyc.org/articulo.oa?id=351562414005

Esta obra está bajo una Licencia Creative Commons Atribución-NoComercial-SinDerivar 3.0 Internacional. 


\title{
Hegemonia do Planejamento Urbano Estratégico e o Discurso Contra-Hegemônico do Direito à Cidade
}

\author{
Hegemony of Urban Strategic Planning and contra-Hegemonic Discourse Of The Right to the City \\ Hegemonia de la Planificación Urbana Estratégica y el Discurso contra-Hegemónico del Derecho a la Ciudad
}

Jouberte Maria Leandro Santos

Instituto Federal de Pernambuco, Brasil

Redalyc: http://www.redalyc.org/articulo.oa?

joubertemaria@gmail.com

Sérgio Carvalho Benício de Mello

Universidade Federal de Pernambuco, Brasil

sergio.benicio@gmail.com

Recepción: 08 Febrero 2018

Aprobación: 22 Abril 2019

Publicación: 01 Abril 2020

\section{Resumo:}

O presente trabalho teve por objetivo avaliar os argumentos que constituem os diferentes discursos acerca do Planejamento Urbano e o Direito à Cidade tendo como foco a construção de um Grande Projeto Urbano (GPU) denominado "Novo Recife". Para tal, acessamos três posições discursivas sobre o assunto: Das empresas que formam o consórcio responsável pela construção, da Prefeitura do Recife e de um movimento social organizado denominado Direitos Urbanos (DU). O método adotado foi a arqueologia foucaultiana e sua análise de discurso. Nossos achados apontam para cinco formações discursivas antagônicas: Duas favoráveis e três contestadoras do modelo de planejamento urbano adotado no Recife.

Palavras-chave: Gestão Pública, Grande Projeto Urbano, Urbanismo Crítico, Gestão Pública, Grande Projeto Urbano, Urbanismo Crítico.

\begin{abstract}
:
The objective of this work was to evaluate the arguments that constitute different discourses about Urban Planning and the Right to the City, focusing on the construction of a Great Urban Project (GPU) called "New Recife". To this end, we accessed three discursive positions on the subject, from the companies that form the consortium in charge of construction, from the City Hall of Recife and from an organized social movement called Urban Rights (DU). The method adopted was Foucaultian archeology and its discourse analysis. Our findings point to five antagonistic discursive formations, two of them favorable and three challenging the urban planning model adopted in Recife.
\end{abstract}

Keywords: Public Administration, Great Urban Project, Critical Urbanism, Public Administration, Great Urban Project, Critical Urbanism.

\section{Resumen:}

El presente trabajo tuvo por objetivo evaluar los argumentos que constituyen los diferentes discursos acerca de la Planificación Urbana y el Derecho a la Ciudad, teniendo como objetivo la construcción de un Gran Proyecto Urbano (GPU) denominado "Novo Recife". Para ello, accedemos a tres posiciones discursivas sobre el asunto: De las empresas que forman el consorcio responsable de la construcción, del Ayuntamiento de Recife y de un movimiento social organizado denominado Derechos Urbanos (DU). El método adoptado fue la arqueología foucaultiana y su análisis del discurso. Nuestros hallazgos apuntan a cinco formaciones discursivas antagónicas, dos a favor y tres desfavorables con el modelo de planificación urbana adoptado en Recife.

Palabras clave: Gestión Pública, Gran Proyecto Urbano, Urbanismo Crítico, Gestión Pública, Gran Proyecto Urbano, Urbanismo Crítico. 


\section{INTRODUÇÃO}

As cidades expressam, das mais variadas formas e dimensões, a organização social de seus sujeitos. Expressam os hábitos culturais e o sistema produtivo de seus habitantes e recebem subvenção do Estado para prestar serviços de interesse público. A cidade contemporânea é fruto da modernidade e de seus padrões estéticos, morais e econômicos e é, sobretudo, reflexo da hegemônica força da economia sobre as dimensões culturais e sociais. Por isso é inquestionável a importância que as cidades assumem na economia e na vida das pessoas.

Situada no litoral nordestino, Recife, lócus de nossa pesquisa, é a capital de Pernambuco e ocupa uma posição central dentre outras metrópoles regionais, como Salvador e Fortaleza. A cidade do Recife nasceu no Porto do Recife, constituído originalmente por um conjunto de estreitas ilhas formadas dos depósitos trazidos pelos rios, pelas correntes marítimas e do aterro de manguezais. Hoje a área do porto é considerada central e altamente valorizada pelo mercado imobiliário.

Neste trabalho iremos analisar a dinâmica entre mercado imobiliário, gestão pública e sociedade civil organizada em torno, especificamente, de uma proposta de um Grande Projeto Urbano (GPU) para área central da cidade do Recife, o projeto Novo Recife, que visa urbanizar uma área onde estão localizados antigos galpões situados no Cais José Estelita, no bairro de São José.

Por ser um cartão postal da cidade, de frente à bacia do Pina, tornou-se uma região cobiçada por várias construtoras. A região foi leiloada em 2008 ao Consórcio Novo Recife, pelo valor mínimo de 55 milhões de reais (Truffi, 2014). De acordo com o Conselho de Desenvolvimento Urbano (CDU), o projeto pretende construir 12 prédios que poderão ter até o tamanho máximo de 40 andares e estacionamentos para 5000 veículos.

Desde 2012, quando o projeto foi lançado, foram movidas mais de cinco ações no ministério público. O projeto revoltou alguns moradores da cidade do Recife que, reunidos em torno do grupo Direitos Urbanos (DU), passaram a liderar e realizar ocupações e manifestações frequentes reivindicando mudanças no projeto e no plano urbanístico da cidade. A principal luta deste movimento social é contra a construção do Projeto Novo Recife, fruto do relacionamento estabelecido entre a Prefeitura Municipal do Recife (PE) e o consórcio de construtoras composto por Moura Dubeux, Queiroz Galvão, Ara Empreendimentos e GL Empreendimentos.

O empreendimento proposto pelo consórcio Novo Recife está rodeado de discussões polêmicas acerca de sua legalidade e impacto na região central do Recife. Diante disso, consideramos o tema relevante e interessante para pesquisa.

Utilizando o método arqueológico de Michel Foucault, consideramos a metodologia aplicada relevante para o avanço do conhecimento científico por entender que o referencial foucaultiano nos aponta um olhar original para os diversos fenômenos sociais na tentativa de descobrir quais são os problemas específicos que vêm construindo e sustentando o nosso cotidiano. Partindo de uma concepção de que a verdade é produto de condições históricas e contingenciais, buscamos compreender os argumentos empregados por esses agentes na composição de seus discursos com relação à configuração de Grandes Projetos Urbanos (GPUs) e sua efetividade para um bom Planejamento Urbano. Com base nisso, esta pesquisa foi norteada pela seguinte pergunta de pesquisa: Que argumentos formam os discursos acerca do modelo de Planejamento Urbano do Recife e sua utilização dos GPUs? 


\section{Fundamentos Teóricos}

\section{O Planejamento Urbano Estratégico e o Uso de GPUs}

Nunca, em nenhum período anterior da história, uma parcela tão elevada da população viveu nesta invenção humana denominada cidade. Em 2014, segundo dados da Organização das Nações Unidas (ONU), cerca de $54 \%$ da população mundial vivia em cidades. As projeções mostram que 2,5 bilhões de pessoas viverão em centros urbanos até 2050. Já são 28 cidades no mundo onde vivem 453 milhões de pessoas, $12 \%$ da população mundial (ONU, 2014). Por isso, é inquestionável a importância que as cidades assumem na economia e na vida das pessoas.

Henri Lefebvre argumentava que nos centros das cidades medievais prosperavam o comércio de mercadorias. Eram centros de vida social e política e de acúmulo de bens, conhecimentos, técnicas e obras de arte. Nesta perspectiva, a própria cidade é uma obra e tem valor de uso. "O uso principal da cidade, isto é, das suas ruas e praças, dos edifícios e dos monumentos, é a Festa” (Lefebvre, 2001, p. 12). A cidade funcionava pela escala humana, ou seja, sua estrutura comportava o homem e suas limitações. Com o advento da Revolução Industrial, mudanças começaram a modificar a estrutura urbana e o homem deixou de ser a medida para a organização e planejamento da cidade, dando lugar à máquina (fábricas). As cidades tornaram-se sistemas reprodutivos (Lefebvre, 2001).

O planejamento urbano apoiado pelo Estado foi essencial para manter a integridade deste projeto de cidade que privilegia a máquina em detrimento do homem. Suas práticas e teorias arquitetônicas associadas apoiaram a "racionalização" das paisagens urbanas inteiras, baseadas em noções de racionalidade, ciência, tecnologia, além da celebração e das ideias “modernas" de estética. A partir da Revolução Industrial, grande parte da política urbana foi dominada por questões de investimento em infraestrutura e tecnologia. Cidades ocidentais, em particular, estavam na transição da cidade comercial compacta, mais antiga, para a nova metrópole industrial com um núcleo forte e um anel de bairros residenciais. Em todo o mundo urbano, pequenas ilhas fragmentadas juntaram-se e padronizaram-se para formar as metrópoles que conhecemos hoje (Graam \& Marvin, 2001).

Com todas essas transformações, o urbanismo moderno segue o que Borja e Castells (1999) chamaram de planificação normativa, também conhecida como empresariamento urbano (Harvey, 2007), empresarialismo (Fernandes, 1997) e Planejamento Urbano Estratégico(Lopes, 1998). Trata-se de um modelo administrativo de planejamento urbano, inspirado em técnicas e conceitos oriundos do planejamento empresarial, segundo o qual a cidade deve ser pensada do ponto de vista de uma empresa. O planejamento estratégico, segundo seus defensores, deve ser adotado pelos governos locais em razão de estarem as cidades submetidas às mesmas condições e desafios que as empresas.

Com este modelo, no decorrer dos anos, os atores econômicos foram exercendo, gradativamente, ainda mais influência na governança das cidades. No Brasil, esta influência cresceu em importância a partir dos anos 1990, sob o teto do neoliberalismo, que prescreve a participação do setor privado como requisito para uma boa gestão pública. Esta ideia está imbricada na maioria dos modelos de empreendedorismo urbano das cidades brasileiras que passam a ser protagonistas de experiências centradas na junção entre público e privado na gestão de seus territórios (Leal, 2012). Segundo Castells e Borja (1996), esta visão baseia-se na ideia de que as cidades são instrumentos eficazes para dar respostas às crises e para atender às aspirações de inserção econômica no contexto global, o urbano é lugar de reproduzir capital das mais diversas formas possíveis.

Ao longo dos processos de implantação deste modelo em várias cidades ao redor do mundo, percebeuse o Planejamento Urbano Estratégico como um modelo de gestão urbanística marcado por rigidez nos procedimentos e pela exclusão do conflito social na tomada de decisões, por um racionalismo extremo expresso nos modelos de cidades muitas vezes zonificados e segregados, por um processo burocrático lento em relação às transformações sociais, pela promoção de um crescimento econômico em busca de uma 
ocupação do espaço natural sem limites, por uma administração centralizada e hierarquizada em setores e pela permissividade com o mercado e os agentes econômicos mais poderosos. No Brasil, "planejamento estratégico" teve sua crítica fundamental construída por autores como Milton Santos $(2003 ; 2013)$ e Carlos Vainer (2000; 2003).

Milton Santos, em “A Urbanização Brasileira”, expõe os resultados desastrosos desse modelo de gestão e argumenta que o processo brasileiro de urbanização revela uma crescente associação com a pobreza:

A cidade em si, como relação social e como materialidade, torna-se criadora de pobreza, tanto pelo modelo socioeconômico de que é o suporte como por sua estrutura física, que faz dos habitantes das periferias (e dos cortiços) pessoas ainda mais pobres. A pobreza não é apenas o fato do modelo socioeconômico vigente, mas, também, do modelo espacial (Santos, 2013, p. 10).

Quando a conjuntura econômica negativa, como ajuste inflacionário e crise fiscal, acontece e repercute sobre os governos locais e municípios de uma cidade, isso aguça ainda mais o sentimento de crise, o que estimula acordos, por parte de dirigentes governamentais e municipais, com paradigmas que podem ser considerados um processo de venda das cidades (Leal, 2012).

É um processo que vai na contramão do tradicional planejamento físico-territorial, esse modelo de planejamento considerado estratégico passa a enfatizar a implementação dos chamados grandes projetos de desenvolvimento urbano ou Grandes Projetos Urbanos (GPUs) como vetores privilegiados e estruturantes do desenvolvimento. Os GPUs são formas complexas de articulação entre o público e o privado, referentes ao território, acionadas a fim de superar a propalada “ineficácia” da ação do Estado. Usualmente, os GPUs vêm justificados com base em uma representação do mundo contemporâneo que privilegia as articulações com a escala global e têm por estratégia "potencializar recursos para desencadear processos de desenvolvimento econômico e promover efeitos de reestruturação no espaço urbano" (Oliveira \& Lima, 2009, p.6). A expressão GPUs tornou-se conhecida no Brasil a partir da década de 70 quando passaram a ser implantados no país projetos de investimentos, que por suas dimensões técnicas e financeiras, revelaram-se muito superiores aos empreendimentos até então existentes (Bortelo, 2001). São exemplos recentes desses tipos de projetos, as obras para a Copa do Mundo sediada no Brasil em 2014 e as Olimpíadas do Rio de Janeiro em 2016.

Desta forma, o modelo urbano característico das cidades que praticam o Planejamento Estratégico e cujos atores econômicos têm papel central é um modelo que dá prioridade a grandes edifícios, grandes vias de circulação e operações imobiliárias especulativas, em detrimento da qualidade de vida das pessoas em seus bairros. Esses planos urbanísticos, projetados segundo critérios econômicos de zonificação, potencializam as diferenças entre centro e periferia, propiciando que alguns bairros fiquem segregados e incomunicáveis.

Os grandes projetos de valorização de áreas centrais, frequentemente apresentando um grande potencial de dinamização econômica, foram se aliando aos objetivos e anseios dos projetos de reforma do Estado, que apostou na crescente articulação e cooperação entre poder público e setor privado para a implementação de GPUs, na tentativa de fazer com que a cidade assuma um papel bem mais proativo no campo econômico, além de recorrer à prática do Planejamento Estratégico na definição de suas prioridades de desenvolvimento. A "receita mágica" seria num novo tipo de parceria criativa. Competividade, empreendedorismo, planejamento estratégico por projetos e intervenções pontuais articulam-se e passam a compor o rol das iniciativas a ser adotadas pelas prefeituras.

Esta gestão estratégica pressupõe não apenas a presença de um governo local, mas uma coalizão de forças globais e locais denominada de governança urbana, que, segundo Mascarenhas (2014), tem como premissa a atuação conjunta do governo local, da iniciativa privada e da sociedade civil. A premissa implícita deste discurso, segundo Souza (2006, p. 129), é a de que "o que é bom para as empresas e faz a prosperidade econômica aumentar também acaba sendo bom para a população em geral”. Desta forma, o papel do Estado é de pactuar e construir acordos e negócios que permitam a promoção da imagem da cidade.

Uma cidade empresa ou mercadoria está sempre em busca de negócios. Sempre em competição com as demais cidades da sua região e do seu país. Conduzida sempre como uma empresa, com comandos claros de 
quem detém o capital, a cidade deve sempre estar unida para competir, por isso, as campanhas de marketing urbano promovem a unidade entre os citadinos e a eliminação dos conflitos, como se não houvessem diferenças sociais e econômicas profundas na composição das cidades.

Cada vez mais a lógica da gestão empresarial faz-se presente na governança das cidades. Produtividade e competitividade tornaram-se as principais qualidades a serem buscadas pelas cidades. Instituições e agências locais e internacionais como Banco Mundial, Banco Interamericano de Desenvolvimento, Programa das Nações Unidas para o Desenvolvimento e consultores internacionais incentivam a competitividade entre as cidades.

Diante disso, o problema que argumentamos aqui não está no poder privado em si, mas no pensamento hegemônico de transformar a cidade unicamente em um objeto de consumo privado, acessível exclusivamente a uma parcela da população mais favorecida economicamente e com maior proeminência política e social. As correntes que formam o urbanismo crítico, identificadas com a crítica ao ideário neoliberal, expõem esse conflito típico dos excluídos que lutam pelo direito a criar e fazer parte dos espaços urbanos. Esse conflito pode ser traduzido na fórmula "direito à cidade" versus "cidade mercadoria".

\section{O Discurso Contra-hegemônico do Direito à Cidade}

São diversas as tentativas de demonstrar e compreender a complexidade e os problemas que afligem esse modo de vida que é o urbano. Assim, o que se propõe é a possibilidade de viver a cidade da forma mais justa e sustentável possível, de devolver ao homem a sua condição de citadino (Harvey, 2009), permitir ao homem o Direito à Cidade (Lefebvre, 2001).

O Direito à Cidade tem se tornadonos últimos anos um slogan significativo para os teóricos, planejadores, ativistas e cidadãos preocupados com a criação de cidades mais justas e democráticas. Numerosas conferências, textos, documentos políticos, alianças e lutas têm implantado e se unido em torno do termo. Podemos nos questionar sobre o que constitui o direito à cidade? Como isso pode ser entendido hoje? Em termos mais gerais, quais são as perspectivas atuais para democratizar cidades lutando por uma maior justiça social e espacial?

Harvey (2009) explica que "o direito à cidade é muito mais do que a liberdade individual de acessar recursos urbanos: É o direito de mudar a nós mesmos, mudando a cidade” (Harvey, 2009, p.1, tradução nossa). O Direito à cidade afirma-se como um apelo, como uma exigência. A reivindicação à natureza e o desejo de aproveitar a vida urbana são deslocamentos do direito à cidade, uma tentativa de fugir da cidade deteriorada, da vida alienada. Lefebvre popularizou em 1968 este termo, mas não deixou claro o que o direito à cidade significa. Primeiro ele argumenta que "[...] o direito à cidade é como um grito e uma demanda. Este direito serpenteia lentamente através dos desvios surpreendentes de nostalgia e turismo, o retorno para o coração da cidade tradicional, e a chamada de centralidades existentes ou recentemente desenvolvidas" (Lefebvre, 2001, p. 158, tradução nossa). Um pouco mais tarde, o autor tenta ser mais específico e afirma que o Direito à Cidade é

O direito à informação, os direitos de utilização de múltiplos serviços, o direito dos usuários de dar a conhecer as suas ideias sobre o espaço e o tempo de suas atividades em áreas urbanas; também cobriria o direito de utilização do centro (Lefebvre, 1991, p. 34, tradução nossa).

No entanto, Lefebvre deixa claro que o Direito à Cidade não pode ser percebido como um simples direito de visita ou de retorno às cidades tradicionais, mas deve ser entendido como direito à vida urbana transformada (Lefebvre, 2001). Marcuse (2009) defende que o direito à cidade está se tornando, na teoria e na prática, uma formulação ampla, eficaz de um conjunto de exigências a ser pensado e perseguido de forma ativa, mas discute a amplitude do termo que, muitas vezes, pode parecer generalizado, vazio, além disso, questiona que direito é este e em que cidade ele pode ser aplicado. Marcuse sugere que uma teoria urbana crítica pode 
contribuir para a aplicação do direito à cidade na prática. Isto porque uma teoria crítica depende de uma prática crítica e vice-versa. "A teoria urbana crítica é tomada como a análise que flui a partir da experiência da prática no desenvolvimento das potencialidades da sociedade urbana existente” (Marcuse, 2009, p. 2). Uma teoria urbana crítica procura expor as raízes da insatisfação com o modelo urbano, põe luz sobre a situação e tenta fornecer uma explicação não óbvia aos problemas da cidade.

E em relação ao direito? Harvey (2009) afirma não saber quem são os agentes da mudança na sociedade atual. Para Marcuse (2009), o grito ou a aspiração para o Direito à Cidade vem do alienado (intelectuais ou jovens), a demanda vem do excluído. A chamada ao Direito à Cidade não é a todos. Alguns já têm este direito: São os poderes financeiros, políticos, técnicos. É o direito à cidade daqueles que não o tem hoje que nos preocupa.

Marcuse demonstra bem a dimensão do direito nessa relação com a cidade:

O Direito à Cidade é uma reivindicação e uma bandeira sob a qual se mobiliza um lado no conflito sobre quem deve ter o benefício da cidade e que tipo de cidade deveria ser. É uma reivindicação moral, fundada em princípios fundamentais da justiça, da ética, da moralidade, da virtude, do bem. "Direito" hoje não pretende ser uma reivindicação exequível legal através de um processo judicial (embora isso possa ser parte da reivindicação como um passo no sentido de realizar o Direito à Cidade). Pelo contrário, são vários direitos que são incorporados aqui: Não apenas um, não apenas o direito ao espaço público, ou o direito à informação e transparência no governo, ou o direito de acesso ao centro, ou o direito a este serviço ou aquele, mas o direito de uma totalidade, uma complexidade, em que cada uma das partes é parte de um todo único para o qual o direito é exigido (Marcuse, 2009, p. 192, tradução nossa).

Para Harvey (2013), o Direito à Cidade significa o direito de todos nós criarmos cidades que satisfaçam as necessidades humanas, as nossas necessidades. Para o autor, todos devemos ter os mesmos direitos de construir os diferentes tipos de cidades que nós queremos que existam. Para isso, precisamos abraçar a diversidade de anseios urbanos e dos movimentos sociais, em busca, não de um direito ao que já existe, mas de um direito para reconstruir e reinterpretar a cidade como um corpo político diferente do que temos hoje.

Cabe fazer uma distinção entre os direitos nas cidades (no plural) e o Direito à Cidade (no singular). No sentido radical que lhe foi conferido por Henri Lefebvre quando, em 1968, o conceito nasceu nas ruas de Paris, é um grito, uma demanda, uma reivindicação. Trata-se de um slogan (discurso) político, com o objetivo de ampliar o âmbito das demandas de mudança social para englobar a visão de uma sociedade diferente. Outra consideração importante que deve ser feita é que o Direito à Cidade não pode ser concebido simplesmente como um direito individual. Ele demanda esforço coletivo e a formação de direitos políticos coletivos ao redor de solidariedades sociais.

No Brasil, as primeiras lutas urbanas tendo como demanda o Direito à Cidade ganharam importância em meados dos anos 80 do século XX, em torno de uma plataforma da reforma urbana para mudar a realidade de segregação e discriminação e desigualdade nas cidades brasileiras. O marco dessa se luta deu numa coalizão de organizações populares e da sociedade civil denominada Fórum Nacional de Reforma Urbana, que resultou numa emenda popular de reforma urbana na Constituição Brasileira de 1988.

As discussões desse fórum deram origem à lei nacional Estatuto da Cidade e ao Ministério das Cidades. A experiência brasileira de buscar o reconhecimento institucional do Direito à Cidade a partir de uma ação política da defesa da implantação da plataforma da reforma urbana contribuiu para que fosse introduzido, gradativamente, nos Fóruns Internacionais Urbanos, o Direito à Cidade, na pauta dos processos globais voltados a tratar dos assentamentos humanos.

Em 2000, o Fórum Social Mundial tornou-se palco privilegiado para a internacionalização do Direito à Cidade. O processo desencadeado no Fórum Social Mundial, de construção da Carta Mundial do Direito à Cidade, teve como objetivo disseminar a concepção do Direito à Cidade como um novo direito humano, com base numa plataforma de reforma urbana para ser implementada pelos países, visando modificar a realidade urbana mundial mediante a construção de cidades justas, humanas, democráticas e sustentáveis. 
A Carta Mundial do Direito à Cidade contém inicialmente a compreensão do que seja Direito à Cidade e define o que é entendido como cidade e cidadãos. Em seguida, estabelece os princípios do Direito à Cidade. A Carta contém tópicos que tratam dos direitos relativos à gestão da cidade, dos direitos civis e políticas da cidade e dos direitos econômicos, sociais e culturais.

O que seria, então, uma cidade mais humana possível através desse significante que é o Direito à Cidade? Que conceitos devem basear a construção desta cidade? Estes são questionamentos presentes na análise da teoria urbana crítica. Dela surgem diversas soluções utópicas possíveis. Para ser humana esta cidade teria, necessariamente, que ser sustentável, justa, criativa, compacta, democrática, inteligente, habitável, etc.? São muitos os adjetivos empenhados ao longo dos últimos 100 anos na tentativa de estabelecer a cidade ideal para se viver. Baseados no forte humanismo, paradigmas proliferam-se e diversos modelos urbanos vêm sendo criados como, por exemplo: Sustainables Cities, Creative Cities, Compact Cities Educating Cities, Healthy Cities, Democratic Cities, Green Cities, Just Cities, Livable Cities, Resilient cities. Esses modelos urbanos são, de certa forma, todos reivindicados pelo Direito à Cidade nas diferentes cidades e sociedades nas quais o Direito à Cidade se tornou um grito por participação democrática e mudanças urbanas.

No caso do Brasil, por exemplo, o Direito à Cidade não se resume a espaços públicos de qualidade e às demandas mais comuns do norte global. No contexto brasileiro, estamos falando de qualidade em estruturas mais básicas como saneamento básico, direito à moradia, redução da violência. São pautas do século XIX que ainda não foram resolvidas. Essas demandas se juntam a demandas mais atuais como o direito a mobilidade, a comunicação, ao bem público e produz um modo de vida caótico e complexo.

\section{Procedimentos Metodológicos}

Este trabalho é predominantemente qualitativo, porém com algumas diferenças em relação à pesquisa qualitativa tradicional, na medida em que, com suas influências pós-estruturalistas, se opõem aos pressupostos da ciência moderna no que se refere à produção do conhecimento e suas relações com a verdade, pressupostos que, inclusive, busca desconstruir (Merriam, 2002).

Foucault (2014) denomina arquivo o conjunto de dados utilizados para a análise. Segundo o autor, trata-se de um conjunto de práticas discursivas que permite o surgimento dos enunciados. $\mathrm{O}$ arquivo foi constituído por dados coletados por meio de observação direta, entrevistas e dados documentais e foi organizado em três categorias: $\mathrm{O}$ discurso do Consórcio, referente às práticas discursivas das empresas ligadas à construção do Novo Recife; o discurso oficial, referente ao discurso de agentes públicos da Prefeitura do Recife; e o discurso da sociedade civil organizada, referente às práticas do movimento social urbano Direitos Urbanos.

Existem, segundo Creswell (2010), quatro tipos básicos de procedimentos de coleta de dados que são fundamentais na pesquisa qualitativa, a saber: (1) Observação, (2) entrevistas, (3) documentos e (4) materiais audiovisuais. Na composição do nosso arquivo, utilizamos os três primeiros procedimentos de forma a utilizar o melhor de cada método para atingir os objetivos de pesquisa, procurando preservar ao máximo a análise empírica.

Durante o período de coleta de dados participamos de reuniões, eventos, atos públicos e audiências públicas nas quais o movimento Direitos Urbanos participava ou havia convocado e (ou) organizado. Aproveitamos esses momentos para registrar em um bloco de notas apontamentos sobre o que foi visto e presenciado que teria relevância para o esforço analítico do pesquisador, incluindo conversas informais em eventos e informações a respeito do modo de operação das pessoas envolvidas em tais situações. Cada nota de observação realizada foi agrupada em apenas um documento denominado "apontamentos". Além dos dados da observação, foram utilizadas na construção do arquivo entrevistas individuais. A escolha dos primeiros entrevistados foi realizada considerando a frequência de citações de agentes ou instituições nos documentos levantados. A condução das entrevistas ocorreu com o auxílio de um roteiro elaborado para investigar os discursos do movimento. Para efeitos de nossa pesquisa privilegiamos a coleta de entrevistas com integrantes 
que fizeram parte da formação do movimento e que permaneceram no grupo até o fim da coleta de dados. Foram realizadas seis entrevistas com componentes do grupo entre junho de 2016 e março de 2017.

Quanto aos documentos coletados, Creswell (2010) ensina que podem ser documentos públicos (jornais, revistas, etc.) ou documentos privados (diários, anotações, etc.). Creswell (2010) esclarece que os documentos, além de representarem dados relevantes para a pesquisa, podem ser acessados em momentos da conveniência do pesquisador. Decidimos utilizar este procedimento coletando documentos de formas e fontes distintas. Para tanto, realizamos uma criteriosa e consistente seleção de documentos oficiais, artigos, depoimentos e relatórios técnicos e oficiais, conforme discriminado no quadro abaixo.

Quadro 1 - Documentos utilizados na constituição do corpus de pesquisa

\begin{tabular}{|c|c|c|}
\hline Documentos & Sujeito Político & Ano \\
\hline $\begin{array}{l}\text { Relatório da decisão em favor da construção do } \\
\text { Novo Recife }\end{array}$ & $\begin{array}{l}\text { Tribunal Regional } \\
\text { Federal da } 5^{a} \text { Região } \\
\text { (TRF5) }\end{array}$ & 2014 \\
\hline $\begin{array}{l}\text { Apresentação de audiência pública - } \\
\text { Levantamento de indicações de diretrizes } \\
\text { urbanisticas espacializadas a serem observadas } \\
\text { no redesenho do Projeto Novo Recife, } \\
\text { considerando o território do Cais José Estelita e } \\
\text { seu entorno }\end{array}$ & Prefeitura do Recife & 2014 \\
\hline $\begin{array}{l}\text { Audiência Pública Cais José Estelita - Diretrizes } \\
\text { urbanísticas espacializadas a serem observadas } \\
\text { no redesenho do Projeto Novo Recife e entorno }\end{array}$ & Prefeitura do Recife & 2014 \\
\hline Memorial Novo Recife & $\begin{array}{l}\text { Consórcio Novo } \\
\text { Recife }\end{array}$ & 2011 \\
\hline Memorial de Redesenho do Novo Recife & $\begin{array}{l}\text { Consórcio Novo } \\
\text { Recife }\end{array}$ & 2014 \\
\hline Relatório de Redesenho do Novo Recife & $\begin{array}{l}\text { Consórcio Novo } \\
\text { Recife }\end{array}$ & 2014 \\
\hline $\begin{array}{l}\text { Cais José Estelita ganhará parque, ciclovia e } \\
\text { biblioteca pública }\end{array}$ & $\begin{array}{l}\text { Diário Oficial - } \\
\text { Prefeitura do Recife }\end{array}$ & 2013 \\
\hline $\begin{array}{l}\text { Mensagem à Câmara destaca resultados para um } \\
\text { novo Recife }\end{array}$ & $\begin{array}{l}\text { Diário Oficial - } \\
\text { Prefeitura do Recife }\end{array}$ & 2014 \\
\hline Novo Recife - O Projeto & $\begin{array}{l}\text { Consórcio Novo } \\
\text { Recife }\end{array}$ & 2014 \\
\hline
\end{tabular}

Fonte: Elaborado pela autora.

Como método de análise, adotamos a análise do discurso foucaultiana, com base em sua analítica arqueológica, que se propõe à descoberta das condições de possibilidade de certos saberes (Foucault, 2014). Tal abordagem debruça-se sobre os discursos para compreender as formações que o caracterizam. Foucault, em "A ordem do discurso", afirma que todo discurso é produzido em razão de relações de poder e que em toda sociedade a produção do discurso é ao mesmo tempo controlada, selecionada, organizada e redistribuída por certo número de procedimentos que "têm por função conjurar seus poderes e perigos, dominar seu acontecimento aleatório, esquivar sua pesada e temível materialidade" (Foucault, 2005, p. 09). O discurso, na obra foucaultiana, não é simplesmente o que favorece os sistemas de dominação, "mas aquilo por que e pelo que se luta, o poder do qual queremos poderar" (Foucault, 2005, p. 10). Por isso, para Foucault (2005), o discurso não está apenas na fala, mas no fazer as coisas. Não está apenas no que é dito ou feito, mas no que deixa de ser dito ou feito dentro das relações nas quais os discursos são construídos.

Para Foucault (2008, p. 133), discurso é "um conjunto de enunciados, na medida em que se apoiem na mesma formação discursiva”. Desta forma, apresenta as formações discursivas como um grupo de enunciados, dotados de funções, que seguem certas regras. No quadro a seguir apresentaremos as categorias analíticas desenvolvidas pelo filósofo que serão utilizadas em nossa pesquisa: 


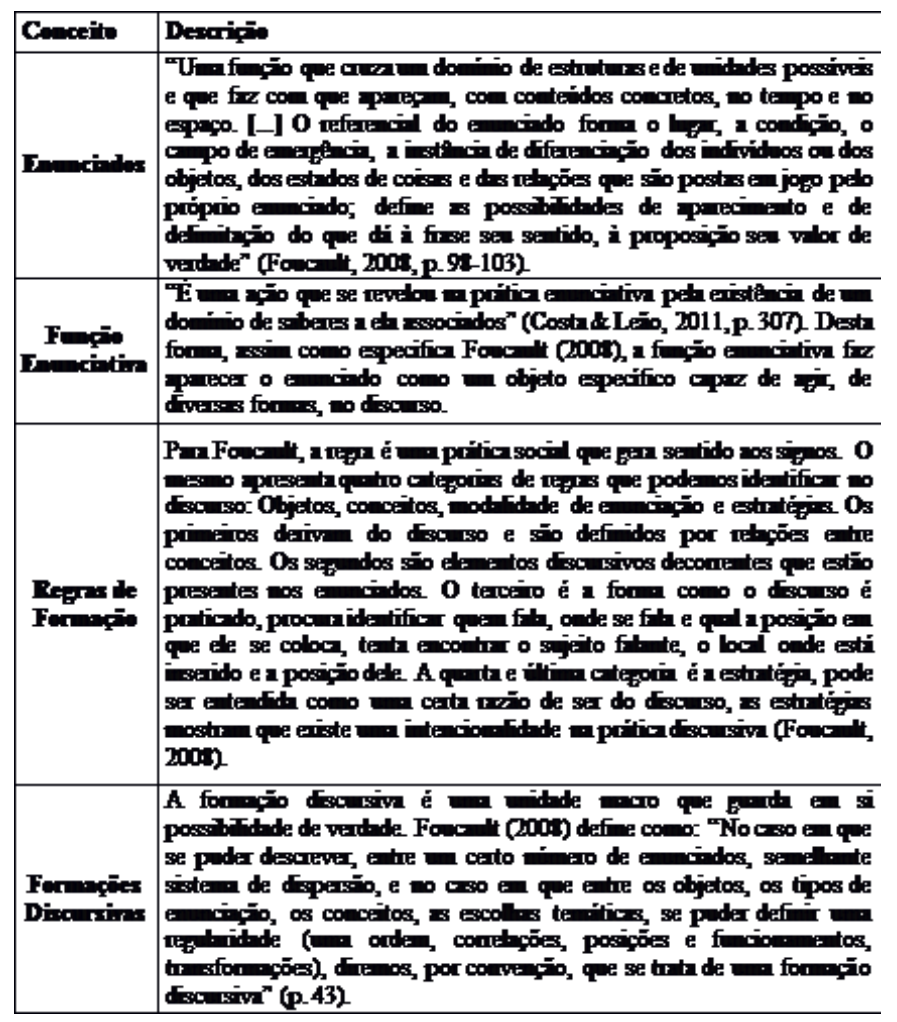

Quadro 2 - Conceitos utilizados na Análise

Após a identificação dos enunciados, procedemos à identificação das possíveis relações entre os mesmos. O segundo nível analítico buscou revelar as regras de formação e as formações discursivas. Como sinalizamos, para Foucault (2009a), a regra deve ser formada a partir de quatro critérios: Objeto, modalidade, conceito e estratégia. A composição das regras é a etapa reflexiva que se aproxima não apenas do campo empírico, mas do teórico. Nesta fase buscamos aproximar a teoria do campo empírico.

A presente pesquisa foi feita por meio de um caráter indutivo, sem uma teoria em específico como referência, mas apenas os próprios conceitos da arqueologia como um todo, bem como uma visão de mundo pós-estruturalista. Com o início das análises, os discursos caminharam para a discussão entre governança urbana e o direito à cidade, o que nos levou à escolha dos discursos do Planejamento Urbano Estratégico e do Direito à Cidade como base tanto para a própria revisão dessa etapa quanto para o prosseguimento da análise.

\section{ANÁLISE E DISCUSSÃo DOS RESULTADOS}

$\mathrm{Na}$ seção de estratégias metodológicas apresentamos a análise do discurso de matriz foucaultiana para problematizar o fenômeno social estudado. Aqui, desenvolvemos essa análise no intuito de alcançar problematizar o fenômeno. As unidades discursivas do arquivo são os enunciados. Eles constroem o discurso, portanto, desvelam saberes. Cada enunciado provém de uma multiplicidade, mas como cada um faz emergir um saber (verdade) específico, foram transcritos como proposições afirmativas. 66 enunciados revelaram-se nesse campo discursivo.

As funções enunciativas demarcam o desempenho dos enunciados na instância do campo discursivo, ou ainda, no jogo de relações da formação do qual fazem parte. Por serem ações dos enunciados, descrevemo-as como orações que iniciam sempre com um verbo no infinitivo, como por exemplo, "Convencer que o Novo Recife é necessário para melhorar a cidade”, que tem a função de fazer a população perceber o Novo Recife como a melhor opção ambiental e socioeconômica para o centro da cidade do Recife. 
Foram reveladas um total de cinco funções dos sujeitos políticos Prefeitura do Recife e Consórcio Novo Recife e 46 funções enunciativas do sujeito político Direitos Urbanos descritas.

Os enunciados e suas funções levam-nos às regras de formação e seus critérios de regras, que nos ajudaram a revelar as formações discursivas. Nessa etapa o campo revelou 16 regras. Estas regras determinaram as formações discursivas que surgiram como regularidades em meio às irregularidades e descontinuidades desse campo. A partir da relação entre enunciados e funções descrevemos o conjunto de saberes apontando uma verdade particular. Assim, as formações discursivas surgiram por meio da regularidade entre objetos, conceitos, modalidades de enunciação e estratégias.

\section{Formações discursivas}

Nossa análise apontou a existência de cinco formações discursivas. Representamos as formações e seus elementos a partir das relações entre regras, funções enunciativas e enunciados, apoiados na teoria e trazendo ilustrações a partir dos dados.

\section{Planejamento Estratégico é a solução para os problemas urbanos}

A formação discursiva desta seção, "Planejamento Estratégico é a solução para os problemas urbanos", apresentou-se ligada a duas regras de formação: Grandes empreendimentos como solução dos problemas urbanos e expertise administrativa. A primeira regra originou-se entre três funções e nove enunciados, e a segunda entre duas funções e um enunciado. 


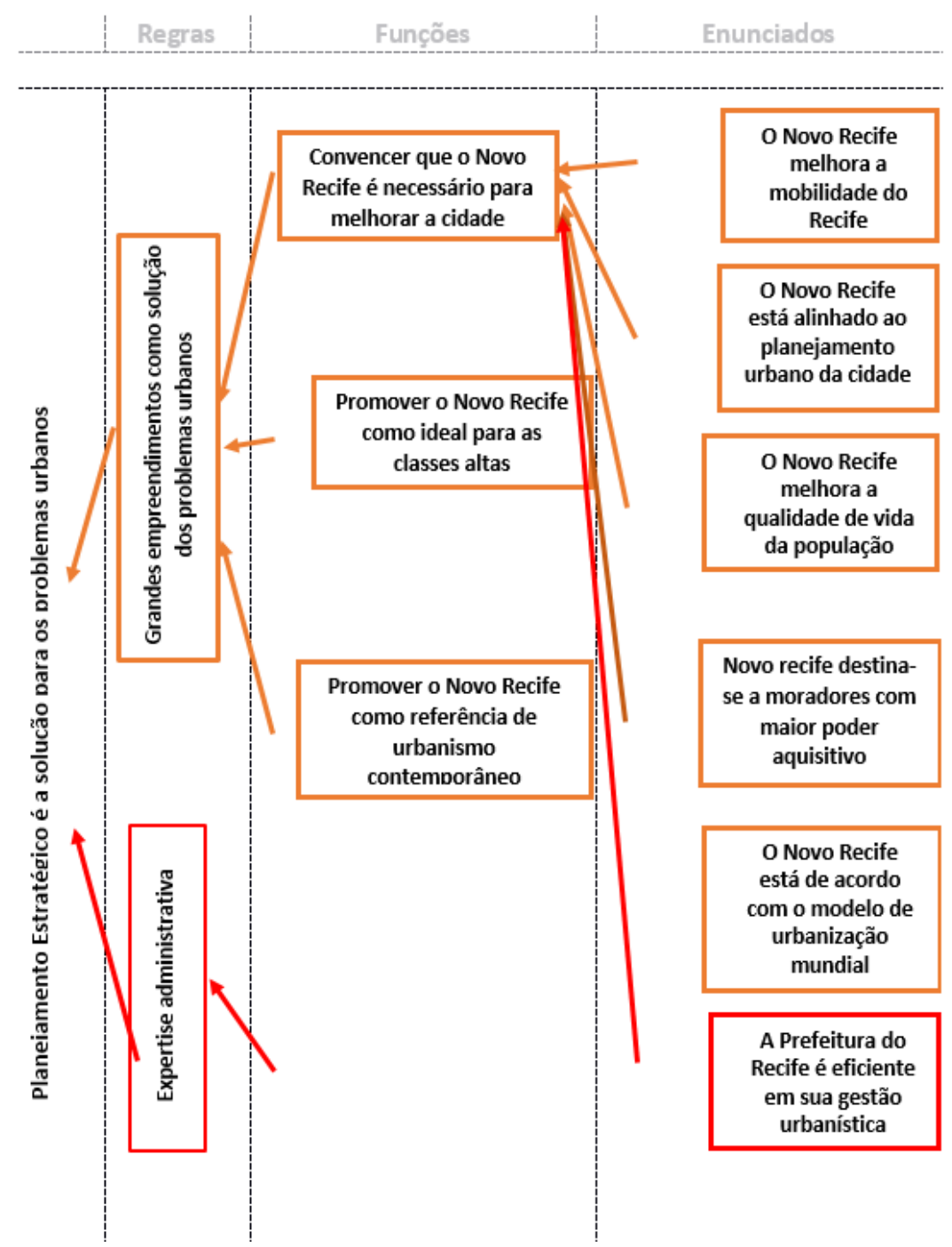

Figura 1: Mapa das relações da Primeira Formação Discursiva

Esta primeira formação discursiva foi gerada a partir de dois campos de saberes distintos, que acessamos pelos dados de dois sujeitos políticos relevantes desse discurso: A prefeitura do Recife e o Consórcio Novo Recife. Assim, todos os enunciados dessa formação foram gerados a partir dos arquivos gerados por esses dois sujeitos e organizados em uma formação, apenas por compartilharem significados semelhantes.

As relações estabelecidas pelos enunciados indicaram para essa formação a existência de dois grupos de significação: Um grupo relativo aos grandes empreendimentos urbanísticos, em que os seis enunciados da formação se relacionaram, indicando a centralidade desse grupo. Esses seis enunciados indicam a promoção dos grandes empreendimentos como ferramenta para urbanização, utilizando o empreendimento Novo Recife como ideal para resolver um problema de espaço abandonado, habitação e mobilidade de uma região central da cidade do Recife. O segundo grupo refere-se à eficiência da prefeitura aliada ao capital privado para resolver os problemas urbanísticos. Nesse grupo surge a centralidade do enunciado "Recife é eficiente em sua gestão urbanística", que exerce a função de convencer sobre a expertise administrativa da prefeitura em gerenciar a cidade. Nesse caso, surgiu também uma relação direta de influência desse enunciado com os três primeiros enunciados da formação, indicando que a Prefeitura do Recife utiliza como modelo urbanístico os grandes empreendimentos e parcerias público-privadas. 
Segundo Borja (1995, p. 276), esse tipo de planejamento está associado ao fato de que "as cidades se conscientizam da mundialização da economia e da comunicação [...]" e, consequentemente, "se produz crescente competição entre territórios e especialmente entre seus pontos nodais ou centros, isto é, as cidades". Neste contexto, nos últimos anos, é possível observar que, no "mercado de cidades", tornou-se necessário garantir um diferencial que destaque determinado centro urbano em relação aos demais.

É generalizado o olhar sempre otimista que acompanha o Planejamento Estratégico, centrado no aproveitamento das oportunidades do mundo globalizado e na inserção competitiva na economia global. Para reforçar essa mensagem, o uso do marketing urbano coloca-se como a estratégia principal, exercendo continuamente uma ação direta sobre o imaginário urbano. Assim, percebe-se forte atribuição de significados positivos ao Planejamento Estratégico, com importante papel das referências a projetos que "deram certo" em lugares distantes. $\mathrm{O}$ trecho seguinte reflete o argumento no caso da cidade do Recife:

O documento entregue na tarde desta segunda (3) reúne, por eixos de atuação, os principais desafios da gestão, com maior detalhamento sobre os programas, projetos e atividades que, somados, resultam na visão estratégica e de futuro. É possível verificar, primeiro, ações consideradas urgentes a serem realizadas; o "dever de casa”, com atuação permanente na manutenção e ordenamento da cidade. Num segundo momento, o relatório ratifica o compromisso assumido pelo prefeito com base no cumprimento do Programa de Governo. E, por fim, o desafio de construir um importante legado para estruturação de uma cidade melhor para se viver, com intervenções estruturadoras para o futuro, propondo-se a ir além do "dever de casa" (Diário Oficial Prefeitura do Recife, 2014).

Tais relações direcionaram a elucidação dessa formação, pois as incidências apontam o Planejamento Estratégico como mote paradigmático da gestão urbanística do Recife. A regra de formação "Grandes empreendimentos como solução dos problemas urbanos" foi desvelada a partir dos critérios de regra, obedecendo a seguinte condição: Objeto - Grandes Empreendimentos; Conceito - Solução, Problemas Urbanos; Modalidade - Informativa, Persuasiva, Promocional; Estratégia - Busca demonstrar os grandes empreendimentos como soluções urbanísticas. Esta regra de formação demonstra claramente como o discurso do planejamento estratégico está presente na gestão analisada na medida em que entende os GPUs como ferramenta ideal para solucionar os problemas da cidade. A Segunda regra, "Expertise administrativa", foi desvelada a partir dos critérios: Objeto - Prefeitura do Recife; Conceito - Eficiência, Eficácia, Gestão; Modalidade - Informativa; Estratégia - Informar eficiência da Prefeitura do Recife.

O documento entregue na tarde desta segunda (3) reúne, por eixos de atuação, os principais desafios da gestão, com maior detalhamento sobre os programas, projetos e atividades que, somados, resultam na visão estratégica e de futuro. É possível verificar, primeiro, ações consideradas urgentes a serem realizadas; o "dever de casa", com atuação permanente na manutenção e ordenamento da cidade. Num segundo momento, o relatório ratifica o compromisso assumido pelo prefeito com base no cumprimento do Programa de Governo. E, por fim, o desafio de construir um importante legado para estruturação de uma cidade melhor para se viver, com intervenções estruturadoras para o futuro, propondo-se a ir além do "dever de casa" (Diário Oficial - Prefeitura do Recife, 2014).

Os enunciados "O Novo Recife melhora a mobilidade do Recife" e "O Novo Recife é melhora da qualidade de vida da população" promovem as contribuições positivas do projeto para a cidade e refletem melhorias no sistema viário da área, considerado problemático, somados a contribuições no melhoramento da paisagem, habitação e lazer para alcançar melhoras na qualidade de vida da população que ali habita e irá habitar quando do projeto finalizado. Dessa forma, a construção de grandes projetos de habitação, lazer, mobilidade, entre outros, são caminhos fundamentais para tornar a cidade a cidade melhor e, consequentemente, mais atrativa.

Segundo o Consórcio Novo Recife, o projeto Novo Recife está de acordo com o Projeto Recife-Olinda (PRO), de 2003, e abrange as áreas dos bairros de São José, Cabanga e os eixos viários Avenida Sul e Rua Imperial da Cidade do Recife, centralizada na margem onde se encontra o Cais José Estelita. Conceitualmente, Grandes Projetos Urbanos (GPUs) são iniciativas de renovação urbana, concentradas em determinados setores da cidade que envolvem agentes públicos e privados, além de investimentos que seguem 
diretrizes de um plano urbanístico apoiado no redesenho do espaço urbano (Someck \& Campos Neto, 2005). $\mathrm{Na}$ Região Metropolitana de Recife, são exemplos de grandes projetos da região o bairro planejado Reserva do Paiva e a Cidade da Copa; em São Lourenço da Mata e na região central, a Via Mangue, e estão em implementação e tramitação legal os projetos Novo Recife e Parque Capibaribe.

É neste ponto que a valorização dos GPUs no planejamento urbano das cidades articula-se com a segunda regra desta formação discursiva, a "Expertise Administrativa". Esta regra anuncia a eficiência da Prefeitura do Recife em resolver problemas urbanos da cidade por estar alinhada a um modelo de planejamento urbano denominado Estratégico. Esses modelos, muitas vezes, são vendidos como a solução para todos os seus problemas, palavras como empreendedorismo, competitividade e planejamento estão presentes na maioria dos atuais projetos de requalificação urbana.

O enunciado "O Novo Recife está de acordo com o modelo de urbanização mundial” demonstra a articulação entre o consórcio, a Prefeitura e influências internacionais nos grandes projetos urbanísticos, principalmente quando se trata da mobilidade, momento relevante na articulação desses discursos. Um dos objetivos principais em gestão urbana estratégica é tornar a cidade mais competitiva através, por exemplo, da restauração dos centros históricos e ações urbanísticas com o objetivo de modificação da imagem da cidade no cenário internacional e nos atrativos turísticos (Vainer, 2000).

As mudanças na gestão pública, que vêm ocorrendo ao longo dos últimos trinta anos, visando adotar esse modelo de "empreendedorismo urbano", configuraram transformações profundas nas formas tradicionais de relacionamento entre a administração pública e o setor privado. Houve um deslocamento da forma clássica de governança, em que havia uma separação clara entre o papel do Estado e do mercado, no qual o primeiro aparecia como contratante e o segundo como contratado. Já no modelo novo de governança pública atual, a interpenetração entre o público e o privado se estabelece sem a presença reguladora do Estado, através dos benefícios das isenções fiscais, do marketing e da apropriação de espaços das cidades. Segundo Leal (2012), essa configuração de governança tem implicado na presença dos interesses econômicos dentro do aparelho do Estado, na sua crescente privatização e na diminuição dos espaços de interesse público em detrimento de sua função social.

O trecho a seguir demonstra que a Prefeitura do Recife está alinhada com esse novo modelo de planejamento: $\mathrm{O}$ estratégico.

Foi a partir da decisão de implantar este novo modelo que a Prefeitura do Recife alcançou os resultados alcançados em
2013. Por meio de um trabalho com foco, planejamento, metas, prazos e acompanhamento sistemático foi possível garantir
investimento recorde já no primeiro ano da gestão de Geraldo Julio. Em 2013, a Prefeitura chegou a marca de R $\$ 530$ milhões
investidos em bens e serviços permanentes à população, superando o montante deR $\$ 121$ milhões dos primeiros anos nas
três últimas gestões (valores corrigidos pelo IPCA). O documento entregue na tarde desta segunda (3) reúne, por eixos de
atuação, os principais desafios da gestão, com maior detalhamento sobre os programas, projetos e atividades que, somados,
resultam na visão estratégica e de futuro [...] (Diário Oficial - Prefeitura do Recife, 2014, p. ).

Este modelo de planejamento estratégico cria uma nova dimensão para a cidade e para a gestão pública: A cidade empresa. A cidade passou a ser vista como uma grande empresa que precisa ser bem gerida para que possa conseguir obter uma alta produtividade e, consequentemente, ser capaz de gerar uma constante e crescente mais valia. Os avanços dos meios de transportes e de comunicações facilitaram a intrínseca capacidade do capital à mobilidade, transformando as relações entre território e investimentos, e "decuplicando a capacidade do capital de investir e reinvestir, ou seja, sua propensão à mobilidade" (Chesnais, 1996, p. 28).

Vainer (2000, p. 84) mostra que o objetivo de transformação da cidade em uma empresa não é apenas no que diz respeito à gestão administrativa, mas segundo ele, “(...) a analogia cidade-empresa constitui a condição mesma da possibilidade da transposição do Planejamento Estratégico de seu território natal (a corporação privada) para o território (público) urbano”. Como visto, o discurso da Prefeitura do Recife está alinhado ao modelo de planejamento estratégico e apresenta uma gestão urbana-empresarial voltada para 
melhorar a eficiência tanto econômica quanto social da cidade. Neste cenário, a cidade envolve-se em uma verdadeira "guerra fiscal" e os lugares tornam-se obrigados a oferecer todos os tipos de vantagens possíveis para se transformarem em sedes das empresas e de outros tipos de investimentos.

Podemos concluir que a implementação de GPUs é um campo privilegiado de legitimação de projetos políticos ou de projetos de poder: Peças do jogo político dos municípios e (ou) estados onde são implementados, quase sempre associados à imagem de uma gestão específica ou de um grupo político. A regra da agilidade e do aproveitamento de oportunidades tende a isentar os GPUs de formas efetivas de controle social. Esse modelo de Planejamento Urbano Estratégico, supostamente, é a melhor possibilidade de reestruturação da cidade em crise, porque tem como objetivo tentar inserir cada vez mais essa cidade em um novo momento e (ou) conjuntura de ampliação da influência da lógica neoliberal nas várias dimensões da vida.

\section{Supremacia do paradigma moderno de urbanidade gera crise urbana}

A formação discursiva desta seção, "Supremacia do paradigma moderno de urbanidade gera crise urbana", apresentou-se ligada a três regras de formação: Grandes empreendimentos como responsáveis pelos problemas urbanos, Recife vive um regime de caos urbano e o progresso é responsável pela crise urbana. A primeira regra originou-se da relação entre doze enunciados e cinco funções, a segunda entre nove enunciados e oito funções, e a terceira entre três enunciados e uma função.

As relações entre enunciados, funções e regras indicaram para essa formação a existência de três grupos de significação: $\mathrm{O}$ grupo sobre as consequências negativas do empreendimento Novo Recife, em que os enunciados dessa formação se relacionam para demonstrar os aspectos ilegais e devastadores do projeto. Um segundo grupo evidencia, através das amarrações entre os enunciados, a crise na cidade, no planejamento urbano de modelo segregador e injusto, e um terceiro grupo que evidencia os resultados negativos do progresso para a cidade.

As relações que direcionaram para a elucidação dessa formação apontam que o planejamento urbano do Recife está baseado na supremacia de princípios do paradigma moderno de urbanidade. Laclau (1990) nos dá um bom exemplo quando afirma o imaginário moderno como o discurso hegemônico no mundo atual. Pois, no imaginário da modernidade a técnica se constitui como vetor de deformação do modelo original, ou seja, os processos de "modernização" são sempre precários e distorcidos em relação ao modelo original. O planejamento urbano também é um discurso que no imaginário moderno foi significado de forma a estabelecer a cidade como base para o crescimento econômico e lugar de fluxo de capital, material, informação e transporte.

Um grupo de enunciados dessa formação discursiva converge para a crítica aos modelos de GPUs e planejamento estratégico, demonstrando que esses modelos estão baseados em uma supremacia do paradigma moderno de urbanidade. A maioria dos projetos urbanísticos são semelhantes ou idênticos, todos seguem o mesmo paradigma moderno de desenvolvimento urbano. A primeira regra dessa formação discursiva, "Grandes empreendimentos como responsáveis pelos problemas urbanos", já anuncia esse antagonismo e essa crítica aos modelos de GPUs.

Assim, para satisfazer interesses particulares de empresários e (ou) políticos, os projetos urbanísticos são desenvolvidos e aprovados sem seguir as leis urbanísticas e ritos de participação popular nessas decisões. Esta lógica está impregnada na forma de administrar a coisa pública na cidade. $\mathrm{O}$ trecho a seguir aborda as críticas feitas pelo Direitos Urbanos à forma como a Prefeitura age de maneira arbitrária:

O caso do Projeto Novo Recife é apenas um caso dentro de uma tendência que já se instalou na cidade há anos e que deve continuar caso nada seja feito. O que é insidioso nesse modelo é que as transformações são feitas pouco a pouco, projeto a projeto, e as discussões acabam reduzidas a questões como se esse galpão ou aquela casa tem valor histórico ou não. Nisso 
perde\#se de vista o grande projeto, o grande paradigma, que, pelas razões acima, é o verdadeiro problema. Discutir o Projeto Novo Recife, portanto, é discutir o futuro da cidade como um todo (Direitos Urbanos, 2012, p. ).

Esse pensamento moderno que guia o modelo de planejamento urbano vigente na cidade foi criado e reproduzido no meio urbano ao mesmo tempo em que determinou sua estrutura, sua estética, sua cultura e seus modelos de vida. Segundo Giddens (1991, p. 8), modernidade "refere-se a estilo, costume de vida ou organização social que emergiram na Europa a partir do século XVII e que ulteriormente se tornaram mais ou menos mundiais em sua influência”.

Entendemos, no entanto, que essa prática de administração das cidades vem sendo contestada por urbanistas críticos (Lefebvre, Harvey, Jacobs, Grahm, etc) e movimentos sociais por todo o mundo (Harvey, 2008). O que esta formação discursiva demonstra é exatamente os efeitos negativos desse modelo influenciado pelo paradigma moderno. A ideia de progresso econômico como caminho para o desenvolvimento da cidade é baseada nesse paradigma moderno, no entanto, como visto, nessa formação aparece como responsável pelo estado de crise urbana atual. A regra "O progresso é responsável pela crise urbana" demonstra a perspectiva do grupo estudado sobre os resultados perversos do progresso para a cidade.

[...] Eu vi que o progresso [de] que se falava tanto era um progresso que não estava produzindo uma cidade tão boa de se viver. Era um progresso que talvez não estava servindo a todas as pessoas da cidade também, a gente sabia que tinha algumas pessoas que não estavam se aproveitando desse progresso, também da cidade, e estava acabando com a memória da cidade e eu imagino e imaginava que não era também um incômodo só meu. Era um incômodo que era compartilhado por todos (Entrevistado 4, 2017).

Nos países do norte global, os sem-propriedade ocupam edifícios velhos e degradados. No sul-global, formam favelas em áreas novas da periferia. É, todavia, aqui, nas metrópoles da periferia do mundo ocidental como Recife, que essa crise adquire sua face mais perversa, submetendo a população à precariedade dos espaços e serviços públicos. Esta crise urbana aflora a herança da desigualdade social nas cidades brasileiras, com a concentração e irregularidade na estrutura fundiária, dificultando a distribuição justa de habitação, desprezo pelo meio ambiente, gentrificação, lei do uso do solo que privilegia as leis de mercado, etc., como pode ser visto nos enunciados que geraram essa formação.

Isto nos leva a última regra de formação desta formação discursiva: Recife vive um regime de Caos Urbano. Os enunciados que formam essa regra demonstram um misto de arbitrariedade com segregação, desorganização, desordenamento e desarranjo, problemas estruturais que culminam em uma entropia que denominamos crise. A cidade do Recife tem um histórico de desigualdade e de problemas urbanos estruturais, ao mesmo tempo em que apresenta uma trajetória de luta de seus cidadãos pelo direito ao solo urbano e habitação (Leal, 2012).

Os processos de revitalização, como qualquer outra intervenção urbana, podem gerar conflitos de interesse entre os atores envolvidos, como prefeitura, empresários, comunidades e cidadãos que, em geral, são os sujeitos que formam as cadeias para essas intervenções urbanas existirem. Segundo o grupo Direitos Urbanos, esses conflitos podem ser amenizados ou resolvidos no processo de diálogo e participação de todas as partes envolvidas. O problema, no caso do Recife, são as formas como esses grandes projetos são implementados na cidade. O projeto Novo Recife, um dos principais alvos de críticas do movimento Direitos Urbanos, vem sendo atacado tanto pela sua formulação, quanto pelo caminho para a sua viabilização.

Há passagens no discurso do DU que esclarece o posicionamento antagônico do grupo ao projeto Novo Recife e ao modelo de planejamento urbano da prefeitura baseados nos princípios modernos já citados anteriormente. Demonstra que as práticas que ocorreram com as articulações para a construção do Novo Recife é uma prática constante da gestão pública da cidade: "O Projeto Novo Recife joga fora uma grande oportunidade de reestruturação do Centro da Cidade e agrava problemas sérios, como o da mobilidade” (Blog Direitos Urbanos, 2012).

A crítica do DU não se resume aos processos de revitalização urbana implementados na cidade, pelo contrário, engloba toda a política urbana, critica um estilo de planejamento considerado cego às vontades e 
necessidades da população e sem respeitar a memória histórica da cidade. Na crítica ao Novo Recife está a preocupação com o futuro da cidade e, principalmente, com o modelo de gestão urbana desenvolvido. Como visto antes, muitas vezes, esses processos de revitalização urbana são acompanhados de uma forte valorização fundiária e imobiliária da área onde ocorrem (Maricato, 2000). No caso do Novo Recife, o DU argumenta que esse projeto só é possível devido “à concentração de poder de decisão nas mãos de políticos e corporações”, que impede uma urbanização sustentável e mais justa para todas as classes sociais da cidade.

\section{A crise urbana do Recife é fruto de uma gestão pública ineficiente e subserviente ao capital}

A formação discursiva desta seção, "A crise urbana do Recife é fruto de uma gestão pública ineficiente e subserviente ao capital”, apresentou-se ligada a duas regras de formação: Uso do poder público em benefício do interesse privado e ineficiência do Estado favorece a crise urbana. A primeira regra originou-se da relação entre sete funções e oito enunciados, e a segunda entre cinco funções e seis enunciados. Com base em Harvey (2007), podemos entender que o planejamento estratégico implementado pela gestão analisada contribuiu para as crescentes disparidades de riqueza e renda, bem como para o aumento da pobreza urbana. Evidenciase a parceria público-privada que, mesmo possuindo uma aparência de neutralidade nas ações de cooperação, acabou por esconder interesses imobiliários e de especulação que a gestão pública ajudou a incentivar.

As relações indicaram a existência de quatro grupos de significação: Um grupo contendo apenas o enunciado "A cidade não é uma mercadoria", um segundo grupo relativo ao papel das elites econômicas na crise urbana, um terceiro grupo a respeito da ineficiência da prefeitura em administrar a cidade e um último grupo evidenciando a crise urbana.

A elucidação dessa formação discursiva deu-se através das relações entre enunciados e suas funções e regras que apontaram como resultado da crise urbana do Recife uma gestão pública ineficiente e servente ao capital. Esta formação discursiva está ligada à formação anterior - Supremacia do paradigma moderno de urbanidade -, já que essa ineficiência na gestão urbana é baseada num urbanismo moderno que segue o que Castells e Borja (1996) chamaram de planificação normativa, e já a desenvolvemos nas seções anteriores. É um paradigma que prega eficiência e eficácia na gestão, mas, na verdade, o que vemos é a utilização de recursos públicos preconizada para alavancar operações urbanas estratégicas de grande porte que têm por destino promover a cidade-global e se choca com a absoluta carência de investimentos públicos em infraestrutura e equipamentos urbanos na cidade periférica, para ficar só no âmbito urbanístico. Enquanto imensas parcelas da cidade não se beneficiam de saneamento, pavimentação, transporte e outros serviços, milhões são investidos na promoção de verdadeiras "ilhas de primeiro mundo" sob a justificativa de que elas serão elementos de "dinamização" da economia como um todo e de requalificação do espaço urbano (Souza, 2006).

Uso do poder público em benefício do interesse privado é uma regra resultante de muitos enunciados frequentes sobre as práticas de gestão da prefeitura do Recife durante o período analisado e demonstra fortemente uma lógica privatista. Um exercício de interesses particulares com o bem público. Não é, necessariamente, fazer do público uma empresa, como visto na formação anterior, mas administrar o público em benefício próprio, de grupos ou de familiares, e ainda entender o público como propriedade privada. Demonstra o abuso de poder em benefício próprio de agentes políticos democraticamente eleitos e sua subserviência a interesses privados de empresários e sujeitos da classe dominante local.

As críticas são à lógica impregnada na gestão urbanística da cidade, que não muda ao longo dos anos analisados, como pode ser visto no enxerto que segue:

Causa-nos indignação profunda que o poder público local esteja fascinado com uma ideia de desenvolvimento e progresso há muito vencida, comprometido com um modelo de cidade que é excludente, predatório e violento, permanecendo ao lado dos grandes empreendimentos imobiliários de luxo; viabilizando com dinheiro público, empreendimentos viários extremamente caros e baseados numa lógica de mobilidade poluente e insustentável (como por exemplo, o projeto para construção de quatro viadutos que o Governo do Estado de Pernambuco não consegue justificar tecnicamente, ambientalmente e socialmente); 
financiando a expulsão da população pobre, através de valorização imobiliária sem contrapartida de desenvolvimento social (Blog Direitos Urbanos, 2012).

Essas críticas também se materializam no enunciado "A cidade não deve ser uma mercadoria". Como mercadoria a cidade tende a adotar um estilo de caraterização que evidencia seus ambientes comerciais, turísticos, geográficos, culturais e históricos.

O enunciado "O capitalismo é responsável pela crise” também evidencia essa crítica. Em algumas falas essa crítica é generalizada ao sistema capitalista como grande responsável por todos os males que a cidade vive: "A verdadeira causa estrutural das múltiplas crises é o capitalismo”. Em muitas outras falas, a crítica não está no capitalismo em si, mas no modo como funciona o mercado imobiliário local e a lógica privatista:

O modelo de negócios da indústria da construção civil em Recife e o modelo de desenvolvimento da prefeitura e do governo do estado baseado nele são pouquíssimo sustentáveis e se assemelha à lógica do extrativismo mais bruto: Obter o máximo de lucro de cada nova área edificável, sem planejamento a longo prazo. (Blog Direitos Urbanos, 2012).

A segunda regra de formação, "Ineficiência do Estado favorece a crise urbana", foi construída com enunciados que evidenciam a ineficiência da gestão pública como maior provocadora da crise urbana:

“Chegamos até aí porque, é óbvio, esse modelo de cidade cada vez mais insustentável e excludente não é um resultado só da atitude predatória dos empresários da construção civil, mas muito mais de uma falha institucional catastrófica” (Blog Direitos Urbanos, 2013).

A Constituição dispõe, no artigo 37, que o serviço público deve ser eficiente. Já no artigo $5^{\circ}$, inciso LXXVIII, afirma que os processos administrativos devem ter razoável duração. Entretanto, sabemos que, de maneira geral, a realidade dos municípios brasileiros não está de acordo com a constituição. Segundo estudo feito pela Fundação Instituto de Pesquisas Econômicas (FIPE), o Brasil não aplica recursos de forma eficiente nos setores que tradicionalmente gere - segurança, educação, saúde e previdência (FIPE, 2007). Referindose ao princípio da eficiência, os autores Berwig e Jali (2007) assim se posicionam:

A inclusão expressa do princípio da eficiência na Constituição da República faz com que o bom resultado nos serviços e um melhor aproveitamento do dinheiro, sejam condutas exigíveis do administrador pela sociedade. Poderíamos dizer que estabelecido como princípio constitucional, a eficiência passa a se constituir direito subjetivo público do cidadão. Esse princípio é uma poderosa arma da sociedade no combate a má administração. Ele dá legitimação para o controle do exercício da atividade do agente público, tanto pelo cidadão como pela própria Administração Pública. E este controle, abrange tanto a competência vinculada, como a discricionária dos agentes públicos. Isso porque o objetivo do princípio da eficiência é a própria satisfação do interesse público (p. 5).

O filósofo Barnett (1976) mostra que o Estado não obedece suas próprias leis e códigos legais. Decorre que se o Estado é incapaz de obedecer às suas próprias leis, então ele é necessariamente ineficiente e autocontraditório como legislador.

\section{Direitos Urbanos é agente de transformação da realidade urbana do Recife}

A formação discursiva desta seção, "Direitos Urbanos é agente de transformação da realidade urbana do Recife”, apresentou-se ligada a duas regras de formação: Direitos Urbanos é um movimento revolucionário e transformador e a participação social contribui para uma cidade mais humana. A primeira regra originouse da relação entre nove funções e doze enunciados, e a segunda entre três funções e três enunciados.

Na primeira regra, "Direitos Urbanos é um movimento revolucionário e transformador", as relações indicaram a existência de dois grupos de significação: Um primeiro grupo relativo ao Ocupe Estelita como luta específica contra a construção do empreendimento Novo Recife na região do Cais José Estelita, em que cinco enunciados dessa formação de algum modo se relacionaram, e um segundo grupo relativo ao Direitos Urbanos propriamente dito, em que seis enunciados se relacionaram para explicar a configuração 
do movimento Direitos Urbanos, suas características, estratégias e principais pautas. Os onze enunciados relacionados caminham para definir o Direitos Urbanos como movimento transformador da realidade urbana do Recife. Esta primeira regra é central na constituição dessa formação, mas, para que a formação discursiva tenha sentido, foi necessária uma articulação com a regra que demonstra a necessidade de participação social nas decisões urbanísticas.

$\mathrm{Na}$ segunda regra revelada, "Participação Social contribui para uma cidade mais humana", as relações indicaram a centralidade de um grupo de enunciados que revelam a crise do sistema democrático que exclui a participação popular dos processos de decisão e afastam os cidadãos das questões sobre a cidade onde vivem. Demonstram ainda a importância da participação popular na construção de uma cidade mais humana.

Tais relações direcionaram a elucidação dessa formação, pois as incidências de relações que levam às regras "Direitos Urbanos é um movimento Revolucionário e Transformador" e "Participação Social contribui para uma cidade mais humana" apontam o DU como agente de mudança da realidade urbana do Recife.

A primeira regra foi desvelada a partir dos quatro critérios de regras, obedecendo à seguinte condição: Objeto - Movimentos Sociais Urbanos; Conceito - Revolução, Transformação; Modalidade - Persuadir, Informar; Estratégia - Persuadir o DU como revolucionário e transformador. A segunda regra foi desvelada pelos critérios: Objeto - Sociedade; Conceito - Participação Social; Modalidade - Persuasiva; Estratégia - Busca por Democracia Direta. Os objetos dessas regras são o movimento social Direitos Urbanos e a participação social. Que movimento é esse e em que condições ele aparece no campo discursivo?

No fim de 2011, alguns amigos interessados em política e preocupados com os problemas da cidade do Recife identificaram um projeto de construção de viadutos na Avenida Agamenon Magalhães. Essa avenida é um dos principais corredores viários da cidade, que abriga em seu entorno uma infinidade de atividades sociais diversas, como igrejas, supermercado, escola, órgãos públicos e edifícios residenciais, entre outros. Esses amigos entraram com uma ação no Ministério Público do Estado reivindicando estudos de impacto de vizinhança e um estudo técnico ambiental da área por entenderem que a construção de uma obra deste porte, neste espaço, iria provocar uma impressionante desagregação social, transformando a vida dos moradores e frequentadores daquela região. Articulando-se com o Ministério Público, instituições e grupos de arquitetos, o grupo conseguiu ser ouvido pela prefeitura.

Logo depois, esse mesmo grupo que se conheciam off-line, foi se expandindo através das redes sociais, principalmente por páginas no Facebook, e começou a transformar suas preocupações em ação também com a reivindicação do tombamento do Edifício Caiçara, situado na Avenida Boa Viagem. Esse edifício, demolido em 2016, era um dos últimos edifícios que representavam o período da ocupação inicial da praia de Boa Viagem, construído no final da década de 30 do século XX, com seu estilo arquitetônico neocolonial tardio, era considerado pelo grupo um símbolo cultural importante que não deveria ter sido arruinado.

Outra mobilização paralela foi contra um projeto de lei que visava proibir o consumo de álcool nas ruas e limitar o horário de funcionamento de bares como medida de combate à violência, por entender que o projeto trazia um ônus à vivência da cidade, criava uma cidade enclausurada, proibida de frequentar um espaço social importante, reforçando, além disso, alguns hiatos entre classes sociais. Segundo o grupo:

Esta mobilização agregou pessoas em torno do desejo comum de participar mais ativamente das decisões políticas que regulam ou interferem na vida social da cidade do Recife, buscando alternativas de ação quando o interesse da cidade fica esquecido pela representação política formal (Blog Direitos Urbanos, 2012).

Foi no dia 22 de março de 2012 que o grupo ganhou o nome Direitos Urbanos. Neste dia aconteceu a primeira audiência pública, convocada pelo grupo, sobre o projeto "Novo Recife" que seria realizado na área do Cais José Estelita.

Foi a primeira vez que se viu publicamente em PowerPoint o projeto, porque até então se tinha saído 2, 3 fotos nos jornais, daqueles $3 \mathrm{~d}$ 's (sic) que eles fazem. E aí nessa audiência pública tanto as pessoas tavam muito vivas ali, muito fortes, pessoas muito diferentes entre si (Blog Direitos Urbanos, 2012). 
Participam do grupo pessoas de diversas áreas, com diferentes graus de experiência no setor privado ou nos governos. Eles se dizem um grupo com intensa interdisciplinaridade, "um lugar onde arquitetos e engenheiros conversam com sociólogos e filósofos e operadores do Direito interagem com artistas plásticos e cineastas; pessoas que aliam o conhecimento técnico com preocupação ética e social" (Blog Direitos Urbanos, 2012).

A partir dessas configurações esse discurso surge no campo discursivo. Os critérios da regra (conceito, modalidade e estratégia) demonstraram a tentativa de emplacar um caráter revolucionário e transformador ao movimento Direitos Urbanos.

Se entendermos o planejamento urbano como um discurso que no imaginário moderno foi significado de forma a estabelecer a cidade como base para o crescimento econômico e lugar de fluxo de capital, material, informação e transporte, quando esse discurso cria condições em que os indivíduos que vivem nesta cidade, em sua maioria, são esquecidos, marginalizados ou excluídos de espaços públicos de lazer, de espaços seguros e de sistemas habitacionais dignos, criam brechas para mudanças acontecerem. Diante de um estado que promete as tais "políticas sociais" e não as executa, os movimentos surgem para denunciar as falhas e, nessas brechas, constituem suas reivindicações.

A conjuntura política que permitiu a emergência no Recife de um novo discurso de cidade pode ser explicada, baseada no aporte teórico deste trabalho, por um momento histórico-global de explosão de manifestações, ocupações e movimentos de cidadãos em protestos contra os problemas urbanos presentes em distintas cidades ao redor do mundo (Harvey, 2013; Soja, 2010), influenciando assim a conjuntura local. As manifestações urbanas em torno de questões como Reforma Urbana e Direito à Cidade foram frequentes ao longo dessas duas últimas décadas em países desenvolvidos e em desenvolvimento. A emergência do discurso do Direito à Cidade é uma demanda ao mesmo tempo local e global, característica latente dos movimentos sociais urbanos (Harvey, 2013).

\section{Reforma e Direito à Cidade como caminhos para uma cidade mais humana}

A formação discursiva desta seção, "Reforma e Direito à Cidade como caminhos para uma cidade mais humana", apresentou-se ligada a seis regras de formação: "A preservação do patrimônio histórico contribui para uma cidade mais humana", "Justiça social contribui para uma cidade mais humana", "A mobilidade urbana de qualidade contribui para uma cidade mais humana", "A sustentabilidade urbana contribui para uma cidade mais humana", "Participação Social contribui para uma cidade mais humana" e "Um novo modelo de cidade é urgente e necessário". A primeira regra originou-se da relação entre duas funções e dois enunciados, a segunda entre duas funções e três enunciados, a terceira entre uma função e dois enunciados, a quarta entre uma função e dois enunciados, a quinta entre duas funções e três enunciados e sexta entre cinco funções e seis enunciados.

Foi a relação entre si estabelecida pelos enunciados que evidenciou as funções dos mesmos. Essa relação indicou para essa formação a existência de três grupos de significação: Um grupo relativo às demandas ou pautas do movimento Direitos Urbanos, em que dez enunciados dessa formação de algum modo se relacionam; um segundo grupo com argumentos e paradigmas de reforma, em que os enunciados demonstram a importância de um planejamento integrado, e um terceiro grupo formado por um enunciado: "Recife vive uma crise urbanística".

Tais relações direcionam a elucidação dessa formação para a necessidade de Reforma Urbana como caminho para nova cidade, considerada mais humana.

A partir das regras de formação geradas pelos enunciados do discurso, identificamos as demandas do DU para uma Reforma Urbana. Os temas e demandas são muitos, com uma análise rigorosa do corpus, condensamos em cinco regras de formação baseadas nos cinco temas que seguem: Preservação do patrimônio histórico, mobilidade eficiente, igualdade social e de direitos, democracia direta e sustentabilidade ambiental. 
A Preservação do patrimônio histórico do Recife articulou diversos sujeitos em prol desta causa. Aparece em vários pontos de discussão do grupo Direitos Urbanos e é uma das justificativas ou motivo principal do grupo contra o Projeto Novo Recife. Considerado um inimigo do patrimônio histórico da cidade. Outra demanda que gerou confluência e que é fundamental na luta pelo Direito à Cidade desempenhado pelo DU no Recife é a questão da mobilidade urbana. Este tema gerou recorrentes enunciados que culminaram na regra de formação "A mobilidade urbana de qualidade contribui para uma cidade mais humana".

As falas analisadas deixam claro a crítica à mobilidade centrada no transporte individual e privado e as consequências negativas que essa prática acarreta para o cotidiano das cidades. As falas contra o projeto Novo Recife e outros implementados no Recife pontuam o pensamento de que a cidade vive um colapso quando o assunto é mobilidade:

Nosso encontro acontecerá no terreno emblemático do Cais José Estelita, em que se planeja a construção de um restrito complexo imobiliário empresarial e habitacional de alto luxo, que prevê a construção de uma dezena de torres, sem consideração ao desenvolvimento sustentável da cidade, alimentando a lógica de mobilidade centrada no uso do transporte individual privado, desconsiderando a história do lugar e o significado da paisagem para as pessoas [...] (Blog Direitos Urbanos, 2012)

O discurso da sustentabilidade também se faz presente na construção dessa formação discursiva através da regra de formação "A sustentabilidade urbana contribui para uma cidade mais humana". A preocupação com a sustentabilidade aparece na fala diversas vezes como fundamental para o futuro do Recife, na crítica à gestão da prefeitura do Recife e aos projetos implementados por ela, como o projeto Novo Recife.

Uma das grandes pautas da agenda do Movimento Direitos Urbanos foi a participação popular na gestão urbana. Vários sentidos foram articulados em torno da necessidade de uma "democracia direta" que permitisse o acesso, a participação e o controle da população no planejamento e nas políticas de urbanização da cidade do Recife. A regra de formação "Participação Social contribui para uma cidade mais humana" reflete a demanda por democracia direta.

Os sentidos fixados em torno dessa demanda são diversos e conglomeram lutas como justiça, participação popular, transparência e acesso à informação. $\mathrm{O}$ direito ao patrimônio histórico, à mobilidade de qualidade, a uma cidade que proporcione melhor qualidade de vida aos seus cidadãos, à participação efetiva do cidadão no planejamento da cidade são demandas que se articulam a uma demanda que não está diretamente ligada às questões urbanísticas que chamaremos aqui de "Igualdade Social e de Direitos", representado pela regra de formação "Justiça social contribui para uma cidade mais humana".

Em 2013, principalmente pela conjuntura de manifestações nacionais que ocorreram em todo o país, o DU articulou demandas como direitos de minorias de mulheres, negros e gays, além de reforço do Estado laico, maior igualdade social, entre outras. Esta demanda expandiu o discurso empregado pelo DU articulando grupos e minorias sociais e suas diferenças a uma cadeia de equivalências em torno da necessidade de Direito à Cidade.

A regra de formação "Um novo modelo de cidade é urgente e necessário", somada às demais regras de formação, compõem um mote para a Reforma Urbana. A ideologia presente no discurso que o movimento Direitos Urbanos tenta normatizar é a de que uma cidade mais justa, democrática e habitável para os cidadãos é aquela feita pelas pessoas. A marca principal do DU, presente em todo o seu discurso, é "Direitos Urbanos - Recife, Porque a cidade é feita pelas pessoas".

O discurso do DU tem como demanda central a Reforma Urbana. Em todas as falas analisadas notase a crítica ao modelo de gestão urbana e a necessidade de uma reforma. No discurso não está claro que reforma é essa e onde é necessário reformar. Há posições diferentes em algumas falas, mas todas convergem para a necessidade de mudar. Entre os anos 2013 e 2014, a Reforma Urbana foi uma demanda frequente na construção do discurso do movimento.

A Carta Mundial do Direito à Cidade estabelece oito princípios a serem seguidos por aqueles que lutam por direito à cidade. Sabemos também a luta pelo Direito à Cidade, apesar de ser um termo genérico, é bastante 
particularizada, seguindo as necessidades de cada local e as demandas dos sujeitos políticos envolvidos. Dos oito princípios propostos pelo Fórum Social Mundial em 2000, alguns foram mais destacados que outros na luta pelo Direito à Cidade liderada pelos Direitos Urbanos e seus aliados. A gestão democrática da cidade, sua função social, o direito à propriedade, o exercício pleno da cidadania, igualdade, proteção especial a pessoas vulneráveis e impulso à economia solidária foram princípios demandados pelo grupo DU. O único princípio não incluído na luta foi o sétimo: Compromisso com o setor privado. Pelo contrário, o setor privado é considerado pelo grupo um setor antagônico, oposto à busca por melhorias das cidades.

Este "Direito à Cidade" articulado no campo discursivo da gestão urbana da cidade do Recife é um "Direito à Recife" com demandas particulares dos sujeitos políticos presentes nesse discurso e com semelhanças e diferenças de lutas por "Direito à Cidade" ao redor do mundo. As demandas do movimento vão além de projetos específicos, que por sua vez, são símbolos de contestação para a transformação da cidade. Há uma demanda clara por Reforma Urbana liderada por um movimento social que emerge do estado de crise urbana que vive a cidade do Recife, na tentativa de construir uma cidade mais humana.

\section{Considerações Finais}

Ao longo deste trabalho buscamos compreender os argumentos empregados por três agentes na composição de seus discursos com relação à configuração de Grandes Projetos Urbanos (GPUs) e sua efetividade para um bom planejamento urbano. Consideramos original o caminho percorrido na análise do arquivo e articulação teórica de campos distintos do conhecimento. Buscamos articular dois campos do conhecimento (Planejamento Urbano Estratégico e Direito à Cidade) através da análise foucaultiana para entender um fenômeno específico e complexo na tentativa de entender suas razões e condições de emergência.

A principal tese de Foucault está na ideia de que todo saber (seja científico ou não) só é possível em determinado momento histórico porque há um espaço de ordem que o possibilita. Nesta perspectiva, o saber é algo como uma visão de mundo compartilhada por todos de uma época, o que Foucault chama de episteme. Mais especificamente, entende-se por episteme "o conjunto das relações que podem unir, em uma dada época, as práticas discursivas que dão lugar a figuras epistemológicas, a ciências, eventualmente a sistemas formalizados" (Foucaut, 2008, p. 214). Ou seja, o que buscamos realizar aqui foi entender o conjunto de relações que permitiu a construção dos discursos acerca do modelo de planejamento urbano do Recife e sua utilização dos GPUs, como demonstrado na pergunta norteadora deste trabalho.

Nossa investigação apontou dois principais discursos antagônicos: De um lado um posicionamento favorável ao modelo de planejamento urbano estratégico, defendido e utilizado pela Prefeitura do Recife; de outro, um posicionamento contrário a este, embasado na convicção de que o modelo de planejamento estratégico é nocivo à cidade, causa crises urbanas e torna o ambiente urbano insustentável.

A hipótese nos revela que o planejamento urbano presente no Recife é resultado de multifatores baseados em premissas do paradigma moderno de urbanidade, premissas essas que fundamentam e reforçam as práticas sociais presentes, somados às características específicas da gestão pública local que reflete práticas herdadas de uma cultura coronelista, típica de países com histórico escravocrata.

Neste processo de "modernização" dos espaços, a cidade foi construída e destruída para dar lugar ao progresso. Ao longo desse processo, a metrópole Recife transformou-se em um caldeirão de frustrações dos habitantes e de demandas não atendidas pelo poder público. Diante do caos urbanístico instalado, o poder público cede a outro princípio moderno: $\mathrm{O}$ capital. Deste modo, abre mão da responsabilidade pelo planejamento das cidades e repassa à iniciativa privada, que tem o lucro como prioridade.

Este momento de crise possibilita aberturas para discursos emergentes e (ou) periféricos novos ou antigos, como é o caso do Direito à Cidade. A ação do movimento social estudado neste trabalho demonstra um momento de crise do modelo urbano do Recife e sua emergência possibilita discursos alternativos e contra-hegemônicos. O Direitos Urbanos propõe uma reforma urbana pautada em demandas centralizadas, 
principalmente, em questões de mobilidade, igualdade de direitos, sustentabilidade, preservação do patrimônio histórico e democracia participativa.

Diante da hegemonia do paradigma moderno de urbanidade, o planejamento estratégico, como sua principal criação, empenha-se em estabelecer a separação dos usos interligados pelas redes das infraestruturas, constituindo-se, assim, novas escalas de interesse por funções que servirão ao mercado. Esta atitude ignora a escala humana e descaracteriza os espaços locais.

A problematização desenvolvida ao longo deste trabalho permite perceber que o primeiro grande papel a se exercer de contestação à ordem instituída corresponde a reforçar e amplificar formas de contestação da ideia difundida por esta gestão moderna da cidade de que o direito à cidade se faria presente a partir do acesso da população aos objetos, empreendimentos e símbolos do progresso apontados em projetos como o Novo Recife, que só revelam velhas dinâmicas de comercialização dos espaços da cidade e desprezo pela opinião pública. Há que se reforçar que o direito à cidade advém de uma maior participação de todas as classes sociais das dinâmicas, processos e escolhas de ações e planejamento da cidade. Além do mais, a crítica do movimento contra-hegemônico que analisamos neste trabalho parece nos direcionar até a necessidade urgente de retomar a cidade como uma construção coletiva da sociedade, reafirmando a sua função social, bem como fortalecendo os valores sociais que norteiam as ações individuais e o planejamento da cidade.

\section{REFERÊNCIAS}

Barnett, R. E. (1976). "Fuller, Law, and Anarchism." The Libertarian Forum. p. 5-7.

Berwig A, Jalil, L G. (2007). O princípio constitucional da eficiência na Administração Pública. Rio Grande: Âmbito Jurídico. X, n. 48. Disponível em:http://www.ambitojuridico.com.br/site/index.php? n_link=revista_artigos_\%20leitura\&artigo_id=4536;. Acesso em jan 2017. (Error 1: El enlace externo http:// www.ambitojuridico.com.br/site/index.php?n_link=revista_artigos_\%20leitura\&artigo_id=4536> debe ser una URL) (Error 2: La URL http://www.ambitojuridico.com.br/site/index.php?n_link=revista_artigos_ \%20leitura\&artigo_id $=4536>$ no esta bien escrita)

Borja, J. (1995). Barcelona: un modelo de transformación urbana. Quito: Programa de Gestión Urbana / Oficina Regional para América Latina y Caribe.

Bortoleto, E. M. (2001). A implantação de grandes hidrelétricas: desenvolvimento, discurso e impactos. Vitória: Revista Geografares, n. 2, jun.

Castells, M., Borja, J. (1996). As Cidades como atores Políticos. Novos Estudos CEBRAP, n. 45, julho, pp. 152 a 166.

CHESNAIS, F. (1996). A mundialização do capital. São Paulo: Xamã.

CRESWELL, J. W. W. (2010). Projeto de pesquisa: métodos qualitativo, quantitativo e misto. 2. ed. Porto Alegre: Bookman.

Costa, F.Z. N., Leão, A. L. M. S. (2011). Desvelamento do limiar discursivo de uma marca global em uma cultura local. (pp. 299-332). Cadernos EBAPE, v. 9, n. 2.

Fernandes, S. A. (1997). Empresarialismo urbano e qualidade de vida: mudanças estruturais na gestão em Salvador? Revista de Administração Pública. FGV.v. 31, n. 3.

Foucault, M. (2009a). A Arqueologia do Saber. Rio de Janeiro: Forense Universitária.

Foucault, M. (2005). A ordem do discurso. São Paulo: Editora Loyola.

Foucault, M. (2014). Microfísica do Poder. (28a Ed). Rio de Janeiro: Paz \& Terra.

Foucault, M. (2008). Segurança território, população. Tradução de Eduardo Brandão. São Paulo: Martins Fontes. (Coleção Tópicos).

Giddens, A. (1991). As conseqüências da modernidade / Anthony Giddens, tradução de Raul Fiker. - São. Paulo: Editora UNESP.

Graham, S, Marvin, S. (2001). Splintering Urbanism: Network Infrastructures, Technological Mobilities and the Urban Condition. London, UK: Routledge. 
Harvey, D. (2013). Cidades Rebeldes. São Paulo: Martins Fontes.

Harvey, D. (2009). Condição Pós-Moderna. (18ª Ed). São Paulo: Edições Loyola.

Harvey, D.(2007). De la gestión al empresarialismo: la transformación de la gobernanza en el capitalismo tardío. En D. Harvey (Ed.). Espaciosdel capital. Madrid: Aikal.

Harvey, D.. (2008). The right to the city, New Left Review. (53ª Ed). p. 23-40.

Laclau, E. (1990). Nuevas reflexiones sobre la revolucion de nuestro tiempo. Buenos Aires: Ediciones Nueva Visón.

Leal, S. M. R. (2012). Papel dos atores econômicos na governança das cidades brasileiras. Revista Movimentos Sociais e Dinâmicas Espaciais, Recife: UFPE/MSEU, v. 01, n. 1. 62-82.

Lefebvre, H. (1991). The Production of Space. Oxford: Blackwell.

Lefebvre, H.(2001). O Direito à Cidade. Tradução: Rubens Eduardo Frias. São Paulo: Centauro.

Lopes, R. (1998). A cidade intencional: o planejamento estratégico de cidades. 2. ed. Rio de Janeiro: Mauad.

Marcuse, P. (2009). From critical urban theory to the right to the city. City, 13:2, 185-197.

Maricato, E. (2000). As ideias fora do lugar e o lugar fora das ideias. Arantes, O, Vainer, C e Maricato, E., A cidade do Pensamento Único: desmanchando consensos, 2a. Ed. Petrópolis: ed. Vozes. Rio de Janeiro, Brasil. Recife (1996) Lei de Uso e Ocupação do Solo.

Mascarenhas, G. (2014). Cidade mercadoria, cidade-vitrine, cidade turística: a espetacularização do urbano nos megaeventos esportivos. Caderno Virtual de Turismo. Edição especial: Hospitalidade e políticas públicas em turismo. Rio de Janeiro, v. 14, supl.1, s.52-s.65, nov.

Merriam, S. (2002). Introduction to qualitative research. In: Sharan Merriam. (Org.) Qualitative Research in Practice - examples for discussion and analysis. San Francisco: Jossey-Bass. cap. 1.

Truffi, R. (Junho, 2014). A batalha pelo Cais José Estelita. Carta Capital. Disponível em:http:// www.cartacapital.com.br/sociedade/a-batalha-pelo-cais-jose-estelita-8652.html. Acesso: 10/07/2014.

Truffi, R. (Junho, 2014). A batalha pelo Cais José Estelita. Carta Capital. Disponível em: http:// www.cartacapital.com.br/sociedade/a-batalha-pelo-cais-jose-estelita-8652.html;. Acesso: 10/07/2014. (Error 5: El enlace externo http://www.cartacapital.com.br/sociedade/a-batalha-pelo-cais-jose-estelita-8652.html> debe ser una URL) (Error 6: La URL http://www.cartacapital.com.br/sociedade/a-batalha-pelo-cais-joseestelita-8652.html> no esta bien escrita)

Soja, E. W. Seeking Spatial Justice. Minneapolis: University Of Minnesota Press. 2010.

Someck, N., Campos Neto, C. M. (2005). Desenvolvimento local e projetos urbanos. Arquitextos 059, Texto Especial 059. Disponível em: <http://www.vitruvius.com.br/ revistas/read/arquitextos/05.059/470> . Acesso em: 17 nov. 2017.

Santos, M. (2013). A urbanização brasileira. São Paulo: EDUSP.

Santos, M. (2003). In: Economia Espacial, com Críticas e Alternativas. 2a Edição. São Paulo. Editora: Edusp.

Souza, M. (2006b). Cidades, globalização e determinismo econômico. In: Cidades, v. 3, n. 5. p. 123-142.

Vainer, C. B. Pátria, Empresa e Mercadoria: Notas sobre a estratégia discursiva do Planejamento Estratégico Urbano. In: Carlos Vainer, Otilia Arantes; Ermínia Maricato (Org.). A Cidade do Pensamento Único: Desmanchando Consensos. 1 1 edição. Petrópolis: Vozes, 2000, v., p. 75-104.

Vainer, C. B.. Utopias Urbanas e o Desafio Democrático. REVISTA PARANAENSE DE DESENVOLVIMENTO, Curitiba, n. 105, p. 25-31, jul./dez. 2003.

\section{BY-NC-ND}

